\title{
Pendugaan Parameter Genetik dan Seleksi Karakter Kuantitatif Cabai Rawit (Capsicum annuum L.) Populasi F3
}

\author{
Estimation of Genetic Parameters and Selection on Quantitative Characters of Bird Pepper \\ (Capsicum annuum L.) F3 Population
}

\author{
Abdul Rahman Fajar Sidiq, Muhamad Syukur* dan Siti Marwiyah \\ Departemen Agronomi dan Hortikultura, Fakultas Pertanian, Institut Pertanian Bogor \\ (Bogor Agricultural University), Jalan Meranti, Kampus IPB Darmaga, Bogor 16680, Indonesia \\ Telp. \& Faks. 0251-8629353 e-mail: agronipb@indo.net.id \\ *Penulis untuk korespondensi: muhsyukur@yahoo.com
}

Disetujui 17 Mei 2017/Published online 22 Mei 2017

\begin{abstract}
Bird pepper consumption continues to increase but productivity is still low, which needs plant breeding program for the improvement of yield. This study aimed to analyze the genetic variability, the correlation between the characters, broad sense heritability, and the value of the progress of the selected F3 populations of bird pepper. This research was conducted at the experimental field in Leuwikopo, IPB, Dramaga, Bogor, and at Genetic and Plant Breeding Laboratory, Department of Agronomy and Horticulture, IPB. The experiment using 5 parental and 6 F3 genotypes of bird pepper with 3 replications of parental genotype and without replicating of $F 3$ genotypes. The results showed that the character weight of fruit per plant and number of fruits per plant has a wide genetic variability on all genotypes. All characters observed had positive correlated to yield except of flowering date and date to harvesting. Broad sense heritability values with high criteria were obtained in fruit weight per plant, weight per fruit, and fruit length. Selection index showed great progress in the selected weight per plant and the number of fruits per plant.
\end{abstract}

Keywords: correlation, genetic variability, heritability, selection progress

\section{ABSTRAK}

Konsumsi cabai rawit terus meningkat namun produktivitasnya masih rendah, sehingga diperlukan pemuliaan yang mengarah pada perbaikan daya hasil. Penelitian ini bertujuan untuk menganalisis keragaman genetik, korelasi antar karakter, heritabilitas arti luas, dan nilai kemajuan seleksi populasi F3 cabai rawit. Penelitian ini dilaksanakan di Kebun Percobaan Leuwikopo, IPB, Dramaga, Bogor dan Laboratorium Genetika dan Pemuliaan Tanaman, Departemen Agronomi dan Hortikultura, IPB. Percobaan menggunakan 5 genotipe tetua dan 6 genotipe F3 cabai rawit, dengan genotipe tetua yang diulang sebanyak 3 ulangan dan genotipe F3 tanpa ulangan. Hasil penelitian menunjukkan bahwa karakter bobot buah per tanaman dan jumlah buah per tanaman memiliki keragaman genetik luas pada semua genotipe. Semua karakter pengamatan berkorelasi positif terhadap daya hasil kecuali umur berbunga dan umur panen. Nilai heritabilitas arti luas dengan kriteria tinggi terdapat pada karakter bobot buah per tanaman, bobot per buah, dan panjang buah. Hasil seleksi indeks yang dilakukan menunjukkan kemajuan seleksi yang besar pada karakter bobot buah per tanaman dan jumlah buah per tanaman.

Kata kunci: heritabilitas, keragaman genetik, korelasi, kemajuan seleksi 


\section{PENDAHULUAN}

Cabai merupakan komoditas hortikultura yang cukup penting di Indonesia. Hal tersebut dapat dilihat dari luas panennya pada tahun 2014 menjadi luas panen sayuran tertinggi di Indonesia yaitu 263616 ha (128.734 ha cabai besar dan 134 882 ha cabai rawit) (Kementan, 2014a). Pada tahun 2007 cabai memberikan pengaruh terhadap inflasi lebih tinggi dari gula pasir, sumbangan cabai terhadap inflasi mencapai 0,137 atau sebanding dengan bobot inflasi sebesar 0,24\% (Firdaus, 2015). Jenis cabai yang memiliki potensi besar untuk dikembangkan adalah cabai rawit. Cabai rawit memiliki harga jual tinggi yaitu Rp80 000,00-120 000,00 per kg (Pawardi, 2013). Harga cabai rawit merah per tanggal 25 Juli 2016 mencapai Rp51 600,00 (Disperindag Jabar, 2016). Selain itu, berdasarkan data Survei Sosial Ekonomi Nasional tahun 2009-2013, rata-rata pertumbuhan konsumsi per kapita per tahun cabai rawit mencapai $0.16 \%$, teh $0.13 \%$, sedangkan beberapa komoditas penting seperti beras, jagung pipil, dan bawang merah mengalami penurunan sebesar 1.62\%, 6.33\%, dan 3.67\% (BPS, 2014).

Produksi cabai rawit terus meningkat setiap tahunnya, pada tahun 2013 meningkat 1.60 \% dari produksi tahun 2012. Pada tahun 2014 meningkat sekitar $12.01 \%$ dari tahun sebelumnya (Kementan, 2014b). Meskipun terjadi pertumbuhan produksi, namun produktivitas cabai masih lebih rendah dari potensi hasilnya yang mampu mencapai 12 ton ha $^{-1}$ (Permadi dan Kusandriani, 2006) bahkan bisa mencapai 22 ton ha $^{-1}$ (Syukur et al., 2010a). Perakitan varietas unggul cabai rawit perlu dilakukan sebagai upaya meningkatkan produktivitasnya. Perakitan varietas unggul cabai rawit dapat dilakukan dengan memanfaatkan sumber plasma nutfah cabai rawit hijau dari spesies Capsicum annuum yang memiliki keunggulan umur tanam genjah (Syukur et al. 2015) potensi hasilnya 600 gram per tanaman atau 12 ton $\mathrm{ha}^{-1}$ (Rukmana, 2002).

Pengembangan cabai rawit spesies $C$. annuum sebagai komoditas cabai rawit komersial diawali dengan analisis pewarisan karakter yang berkorelasi dengan tingkat produksi, baik itu karakter kualitatif maupun kuantitatif. Menurut Syukur et al. (2015) karakter kuantitatif dikendalikan oleh gen minor dan banyak karakter penting yang merupakan bagian dari karakter kuantitatif. Analisis pewarisan yang perlu dilakukan meliputi evaluasi keragaman genetik, korelasi karakter, analisis aksi gen, dan heritabilitas. Hal tersebut menjadi dasar dalam melakukan seleksi. Keragaman genetik sangat mempengaruhi keberhasilan suatu proses seleksi dalam program pemuliaan tanaman (Poehlman dan Sleeper, 1995). Karakter yang akan dijadikan kriteria seleksi harus memiliki korelasi positif terhadap produksi. Kemajuan seleksi yang baik akan tercapai jika nilai heritabilitas karakter seleksi tergolong tinggi (Syukur et al., 2015; Wirnas et al., 2006). Interaksi antara aksi gen dan heritabilitas menjadi dasar penentuan metode seleksi yang digunakan (Syukur et al. 2010b) Berdasarkan semua hal itu maka penelitian ini dilakukan dengan tujuan mempelajari keragaman genetik, korelasi antar karakter, heritabilitas serta kemajuan seleksi dari populasi F3 cabai rawit spesies $C$. аппиит hasil persilangan beberapa genotipe.

\section{BAHAN DAN METODE}

Penelitian ini dilaksanakan di Kebun Percobaan Leuwikopo, IPB, Darmaga, Bogor dan Laboratorium Genetika dan Pemuliaan Tanaman, Departemen Agronomi dan Hortikultura, IPB dan berlangsung pada bulan September 2015 sampai April 2016. Materi genetik yang digunakan dalam penelitian ini terdiri atas 5 genotipe tetua dan 6 genotipe generasi ketiga (F3). Genotipe tetua meliputi cabai rawit IPBC160, IPBC293, IPBC145, IPBC291, dan IPBC10, sedangkan populasi F3 terdiri dari genotipe F3160291-9, F3160291-3, F3145293-19, F3145293-7, F310293-13, dan F310293-14.

Bahan lain yang digunakan adalah pupuk anorganik dan organik yang terdiri dari pupuk NPK (16:16:16) dosis $10 \mathrm{~g} \mathrm{~L}^{-1}$, gandasil $2 \mathrm{~g} \mathrm{~L}^{-1}$, dan pupuk kandang kambing 20 ton $\mathrm{ha}^{-1}$. Pengendalian hama menggunakan insektisida berbahan aktif karbofuran dosis $17 \mathrm{~kg} \mathrm{ha}^{-1}$ saat tanam, insektisida dan akarisida bahan aktif diafentiuron dengan dosis $1 \mathrm{ml} \mathrm{L}^{-1}$, insektisida bahan aktif profenofos dosis $2 \mathrm{ml} \mathrm{L}^{-1}$, dan fungisida bahan aktif mankozeb $80 \%$ atau propineb dengan dosis $2 \mathrm{~g} \mathrm{\textrm {L } ^ { - 1 }}$. Alat yang digunakan yaitu peralatan pertanian, timbangan analitik, jangka sorong, meteran, dan penggaris.

Percobaan ini menggunakan rancangan persilangan biparental dengan 11 genotipe cabai rawit (5 genotipe tetua dan 6 genotipe F3). Pada genotipe tetua diulang sebanyak 3 ulangan dan genotipe F3 tanpa ulangan. Setiap petak percobaan berukuran $5 \mathrm{~m} \times 1 \mathrm{~m}$ dengan jumlah populasi setiap petak adalah 20 tanaman. Setiap tetua memiliki total populasi sebanyak 60 tanaman dan setiap genotipe F3 memiliki 60 tanaman. Sehingga keseluruhan percobaan terdiri dari 660 individu tanaman.

Pelaksanaan penelitian dimulai dengan penyemaian benih. Benih setiap genotipe disemai sebanyak satu butir per lubang tray yang berisi media semai yang terdiri atas kompos dan arang 
sekam dengan perbandingan 1:1. Penyiraman dilaksanakan setiap hari pada pagi dan sore hari. Pemupukan dilaksanakan sejak bibit berumur 3 minggu setelah semai (MSS) hingga 6 MSS, dengan periode 1 minggu sekali menggunakan pupuk NPK (16:16:16) dosis $10 \mathrm{~g} \mathrm{~L}^{-1}$ dan gandasil $2 \mathrm{~g} \mathrm{~L} \mathrm{~L}^{-1}$. Penyemprotan pestisida dilakukan menggunakan insektisida dan akarisida berbahan aktif diafentiuron dengan dosis $1 \mathrm{ml} \quad \mathrm{L}^{-1}$. Pengendalian gulma dilakukan secara manual. Pengolahan lahan dan pembuatan bedengan dilaksanakan bersamaan dengan kegiatan penyemaian. Bedengan dibuat dengan panjang 5 $\mathrm{m}$, lebar $1 \mathrm{~m}$, tinggi $30 \mathrm{~cm}$, dan jarak antar bedeng $50 \mathrm{~cm}$. Ditambahkan pupuk kandang kambing saat pengolahan lahan. Setelah bedengan siap maka dilakukan pemasangan mulsa plastik hitam perak, kemudian dibuat lubang tanam menggunakan cemplongan dengan jarak tanam 50 $\mathrm{cm} \times 50 \mathrm{~cm}$. Bibit dipindah ke lapang setelah berdaun 4-5 helai atau berumur 6 MSS. Setiap lubang tanam ditanami satu bibit. Pada umur 1 minggu setelah tanam (MST) dilakukan penyulaman. Pada saat melakukan penanaman diaplikasikan insektisida berbahan aktif karbofuran dengan dosis $17 \mathrm{~kg} \mathrm{ha}^{-1}$. Pemeliharaan tanaman yang dilakukan meliputi pengajiran, penyiraman, penyulaman, pemupukan, pewiwilan, dan pengendalian OPT. Pengajiran dilakukan bersamaan dengan penanaman. Pemupukan dilakukan setelah tanaman berumur 1 MST dengan aplikasi pemupukan menggunakan larutan pupuk NPK (16:16:16) $10 \mathrm{~g} \mathrm{~L}^{-1}$ yang dilakukan setiap minggu, masing-masing tanaman diberi 250 $\mathrm{ml}$ larutan pupuk. Pewiwilan dilakukan antara umur 7-20 hari setelah tanam (HST). Penyemprotan dilakukan 5 hari sekali dengan menggunakan fungisida mankozeb $80 \%$ atau propineb $2 \mathrm{~g} \mathrm{~L}^{-1}$, insektisida profenovos dengan dosis $2 \mathrm{ml} \mathrm{L}^{-1}$. Pengendalian gulma dilaksanakan secara manual setiap minggu. Pemanenan dilaksanakan pada kondisi buah masak yang ditandai dengan warna buah merah. Pemanenan dilakukan 5 kali secara bertahan setiap 5-7 hari.

Pengamatan dilakukan terhadap karakter kuantitatif dari 10 tanaman contoh yang diambil secara acak dari populasi tetua dan seluruh individu tanaman pada populasi F3. Pengamatan mengacu kepada Descriptor for Capsicum (IPGRI, 1995). Karakter tersebut terdiri dari umur berbunga (HST), umur panen (HST), tinggi tanaman $(\mathrm{cm})$, panjang buah $(\mathrm{cm})$, panjang tangkai buah $(\mathrm{cm})$, diameter buah $(\mathrm{mm})$, bobot per buah $(\mathrm{g})$, jumlah buah pertanaman, dan bobot buah per tanaman $(\mathrm{g})$. Pengamatan umur berbunga dilakukan dengan mengamati jumlah hari setelah tanam hingga tanaman tersebut mulai memiliki bunga mekar sempurna. Umur panen diamati dengan cara menghitung jumlah hari setelah tanam hingga tanaman tersebut memiliki buah masak pada percabangan pertama. Tinggi tanaman diamati dari pangkal batang hingga titik tumbuh tertinggi, dilakukan saat panen pertama. Panjang buah diukur dari pangkal buah sampai unjung buah. Panjang tangkai buah diukur dari pangkal sampai ujung tangkai buah. Diameter buah diukur pada bagian buah yang paling besar menggunakan jangka sorong. Bobot per buah diamati dengan menimbang bobot setiap buah menggunakan timbangan analitik. Jumlah buah per tanaman diamati dengan menghitung jumlah buah total dari 5 kali panen. Bobot buah per tanaman merupakan jumlah bobot buah dari hasil 5 kali panen. Pengamatan panjang buah, panjang tangkai buah, diameter buah, dan bobot per buah dilakukan dengan mengamati 5 buah contoh dari setiap individu tanaman yang diamati.

Data hasil pengamatan kemudian dianalisis untuk mengetahui Koefisien keragaman genetik (KKG), dihitung menggunakan rumus:

$$
\mathrm{KKG}=\frac{\sqrt{\sigma^{2} \mathrm{G}}}{\text { rataan populasi }} \times 100 \%
$$

Analisis lain yang dilakukan adalah menghitung nilai heritabilitas arti luas $\left(\mathrm{h}^{2}{ }_{\mathrm{bs}}\right)$ mengacu pada metode Mahmud-Kramer (Syukur et al., 2015) yaitu

$$
\begin{aligned}
& \mathrm{h}_{\text {bs }}^{2}=\frac{\sigma^{2} \mathrm{~F} 3-\sqrt{\sigma^{2} P 1 \times \sigma^{2} P 2}}{\sigma^{2} \mathrm{~F} 3} \times 100 \%, \\
& \sigma^{2} \mathrm{E}=\sqrt{\sigma^{2} P 1 \times \sigma^{2} P 2}, \\
& \sqrt{\sigma^{2} P 1 \times \sigma^{2} P 2}
\end{aligned}
$$

Keterangan:

$$
\begin{aligned}
\mathrm{h}_{\mathrm{bs}}^{2} & =\text { heritabilitas arti luas } \\
& \sigma^{2} \mathrm{E} \quad=\text { ragam lingkungan } \\
\sigma^{2} \mathrm{~F} 3 & =\text { ragam populasi } \mathrm{F} 3 \\
& \sigma^{2} \mathrm{G} \quad=\text { ragam genetik } \\
\sigma^{2} \mathrm{P} 1 & =\text { ragam populasi P1 } \\
& \sigma^{2} \mathrm{P} \quad=\text { ragam fenotipe } \\
\sigma^{2} \mathrm{P} 2 & =\text { ragam populasi } \mathrm{P} 2
\end{aligned}
$$

$\begin{array}{cccr}\text { Korelasi antar } & \text { karakter pengamatan } \\ \text { diperoleh dengan melakukan analisis }\end{array}$ menggunakan program Minitab 16, perhitungan koefisien korelasi dilakukan pada data kuantitatif untuk menghitung keeratan hubungan antar peubah karakter dengan metode Pearson. Karakter dengan keragaman genetik sedang dan luas, memiliki korelasi positif terhadap daya hasil, serta nilai heritabilitas arti luas yang tinggi digunakan sebagai karakter 
seleksi. Seleksi dilakukan dengan seleksi simultan untuk beberapa karakter menggunakan seleksi indeks. Indeks seleksi dihitung dengan rumus (Falconer, 1981):

$$
I=-Z_{1}-Z_{2}+Z_{3}+2 Z_{4}+Z_{5}+2 Z_{6}+2 Z_{7}+2 Z_{8}+
$$

I adalah nilai indeks seleksi; $Z_{1}, Z_{2}, Z_{3}$, $Z_{4}, Z_{5}, \quad Z_{6}, Z_{7}, Z_{8}$, dan $Z_{9}$ adalah nilai tengah fenotipe yang telah distandarisasi. Peubah $Z_{1}=$ umur berbunga, $Z_{2}=$ umur panen, $Z_{3}=$ tinggi tanaman, $Z_{4}=$ panjang buah, $Z_{5}=$ panjang tangkai buah, $\mathrm{Z}_{6}=$ diameter buah, $\mathrm{Z}_{7}=$ bobot per buah, $\mathrm{Z}_{8}$ $=$ jumlah buah per tanaman, serta peubah $Z_{9}=$ bobot buah per tanaman. Nilai tengah terstandarisasi ini diperoleh dengan melakukan perhitungan menggunakan rumus (Falconer, 1981):

$$
\mathrm{Z}_{\mathrm{n}}=\frac{\mathrm{x}-\bar{x}}{\sigma^{2} \mathrm{E}}
$$

$Z_{n}$ adalah nilai tengah fenotipe terstandarisasi, $\mathrm{x}$ adalah nilai tengah peubah tiap genotipe, $\bar{x}$ adalah nilai tengah populasi, dan $\sigma^{2} \mathrm{E}$ merupakan ragam lingkungan. Setelah memperoleh genotipe terseleksi, maka dihitung kemajuan seleksi dengan menggunakan rumus (Falconer, 1981; Syukur et al., 2015):

$$
\begin{aligned}
& \Delta G=S h^{2} \quad \% \Delta G=\frac{\Delta G}{\bar{x}_{p}} \times 100 \% \\
& \mathrm{~S}=\left|\bar{x}_{t}-\bar{x}_{p}\right|
\end{aligned}
$$

Peubah $\Delta \boldsymbol{G}$ adalah kemajuan seleksi, $\boldsymbol{h}^{2}$ adalah heritabilitas, $\mathrm{S}$ adalah diferensial seleksi ,$\overline{\boldsymbol{x}}_{\boldsymbol{t}}$ adalah nilai tengah populasi terseleksi, dan $\overline{\boldsymbol{x}}_{\boldsymbol{p}}$ adalah nilai tengah awal populasi. Semua analisis data ini dilakukan menggunakan perangkat lunak Microsoft Excel 2010.

\section{HASIL DAN PEMBAHASAN}

\section{Kondisi Umum}

Penelitian ini dilaksanakan di Kebun Percobaan Leuwikopo IPB dengan ketinggian 207 $\mathrm{m}$ dpl. Penelitian dilaksanakan bulan September 2015 - April 2016. Daya tumbuh benih cabai rawit di persemaian berkisar antara 45,14 $62.22 \%$ dengan rata-rata $54.59 \%$. Daya berkecambah ini tergolong rendah karena menurut Kusandriani dan Muharam (2005) menyatakan daya berkecambah pada cabai tergolong tinggi jika persentase daya berkecamabah lebih dari 80\%. Suwandi et al. (1999) menjelaskan bahwa faktor-faktor yang mempengaruhi vigor benih adalah kondisi lingkungan selama perkembangan benih, kondisi genetik benih, dan lingkungan penyimpanan.

Penelitian dilaksanakan pada awal memasuki musim penghujan, dimana curah hujan di awal masih rendah dan di akhir penelitian cukup tinggi. Kondisi iklim di sekitar lahan meliputi curah hujan berkisar 21.8-673.2 mm. Curah hujan tertinggi pada bulan November 2015 (673.2 $\mathrm{mm})$ dan terendah pada bulan September $2015(21.8 \mathrm{~mm})$. Kelembaban udara berkisar 72.6-84.6\% dan suhu udara berkisar $26,1-26,8^{\circ} \mathrm{C}$ (BMKG Darmaga, 2016). Lahan yang memiliki kelembapan dengan suhu yang tinggi mengakibatkan banyaknya penyakit yang menyerang selama penanaman.

Penyakit yang menyerang saat pertanaman ditemukan adalah rebah kecambah, layu bakteri, layu fusarium, penyakit virus kuning, dan busuk buah antraknosa. Rebah kecambah yang disebabkan oleh cendawan Pythium spp. menyerang pada saat persemaian hingga awal pindah tanam. Layu bakteri (Ralstonia solanacearum), layu fusarium (Fusarium oxysporum), penyakit virus kuning atau gemini virus, dan busuk buah antraknosa (Colletotrichum sp.) menyerang tanaman di lahan pertanaman sejak fase vegetatif hingga generatif selesai. Penyakit layu bakteri dan antraknosa dapat menurukan hasil secara berturut-turut sekitar 2344\% dan 19-63\% (Maharijaya dan Syukur, 2014). Hama yang dominan menyerang adalah kutu daun (Myzus persicae), tungau (Polyphagotarsonemus latus), dan trips (Thrips parvispinus). Kutu daun menyerang di persemaian dan di lahan, namun intensitasnya terus menurun seiring dengan pertambahan umur tanaman dan pendewasaan jaringan. Kelimpahan $M$. persicae pada tanaman cabai rawit erat kaitannya dengan aktivitas metabolisme tumbuhan (Kennedy dan Stroyan, 1959), kuantitas serta kualitas nutrisi di bagian tumbuhan itu (Awmack dan Leather, 2002). Selain itu berkurangnya serangan kutu daun juga dipengaruhi oleh penggunaan mulsa plastik perak hitam. Hampir semua spesies kutu daun menghindari pantulan cahaya perak (Blackman dan Eastop, 2000). Penggunaan mulsa plastik perak lebih baik dalam mengendalikan hama $M$. persicae dibandingkan mulsa hitam (Utama et al., 2015).

\section{Keragaman Genetik dan Korelasi Karakter Populasi F3 Cabai Rawit (Capsicum annuum L.)}

Petani cabai rawit saat ini masih menggunakan varietas lokal yang umumnya berdaya hasil masih rendah dan jauh dari potensi hasil cabai yang mampu mencapai 22 ton ha ${ }^{-1}$ (Syukur et al., 2010a). Perakitan varietas unggul 
cabai diarahkan pada perbaikan daya hasil, karakter hortikultura, dan ketahanan penyakit (Greenleaf, 1986). Proses perakitan varietas unggul cabai rawit diawali dengan menganalisis keragaman genetik. Besaran keragaman genetik sangat berpengaruh terhadap keberhasilan seleksi dalam pemuliaan tanaman (Poehlman dan Sleeper, 1995).

Keragaman genetik suatu populasi tergantung pada apakah populasi tersebut masih menjadi bagian dari populasi bersegregasi, tingkat generasi ke berapa, dan bagaimana latar belakang populasinya (Pinaria et al., 1995). Populasi yang digunakan dalam penelitian ini berada pada generasi ketiga yang merupakan keturunan pertama dari generasi dengan tingkat segregasi tertinggi (F2). Sehingga pada populasi ini masih memiliki keragaman yang cukup besar. Hasil analisis ketidakmiripan yang dilakukan Undang (2014) menunjukkan bahwa tingkat ketidak miripan dari 5 genotipe tetua yang digunakan dalam penelitian ini (IPBC160, IPBC145, IPBC293, IPBC291 dan IPBC10) memiliki tingkat ketidakmiripan pada kisaran nilai ketidakmiripan 5 hingga 10. Semakin tinggi nilai ketidakmiripan mengindikasikan kemiripan morfologi antar genotipe semakin jauh. Hal tersebut mendukung terbentuknya genotipe hasil persilangan dengan keragaman genetik luas.

Keragaman genetik suatu karakter dapat dilihat dari rentang sebaran data karakter tersebut (Syukur et al., 2010c). Keragaman genetik juga dapat dilihat dari persentase koefisien keragaman genetik (KKG) karakter yang diamati. Alnopri (2004) menggolongkan keragaman genetik menjadi 3 kriteria yaitu sempit jika nilai KKG 0$10 \%$, sedang jika KKG bernilai $10-20 \%$, dan luas jika nilai KKG lebih besar dari 20\%. Hasil penelitian menunjukkan bahwa seluruh karakter pengamatan memiliki rentang data yang cukup besar dan nilai KKG pada kriteria sempit hingga luas, kecuali umur berbunga yang memiliki KKG hanya pada kriteria sempit.

Umur berbunga pada seluruh populasi F3 yang diamati memiliki keragaman genetik yang sempit ini sejalan dengan penelitian sebelumnya yang dilakukan oleh Yunianti et al. (2010) dan Syukur et al. (2011). Keragaman yang sempit ini menunjukkan bahwa seluruh populasi F3 memiliki umur berbunga yang sudah relatif seragam. Karakter umur panen, panjang buah, panjang tangkai buah, dan diameter buah memiliki keragaman genetik sempit hingga sedang, hal ini berbeda dengan penelitian sebelumnya yang menunjukkan bahwa terdapat keragaman genetik yang luas untuk karakter umur panen (Syukur et al. 2010c), panjang buah (Lestari et al., 2006; Yunianti et al., 2010; Syukur et al., 2011), diameter buah (Lestari et al., 2006; Yunianti et al., 2010; Qosim et al., 2013). Tabel 1 menyajikan data rataan, rentang, dan KKG beberapa karakter penting cabai rawit yaitu bobor per tanaman, bobot per buah, dan jumlah buah. Rentang data yang luas dan nilai KKG lebih besar dari 20\% ini menjadikan karakter bobot per tanaman, bobot per buah, dan jumlah buah pertanaman memiliki keragaman genetik yang luas. Sejalan dengan penelitian sebelumnya yang menunjukkan bahwa terdapat keragaman genetik yang luas bobot buah (Sreelathakumary dan Rajamony, 2004; Yunianti et al., 2010; Syukur et al., 2011), bobot buah per tanaman (Sreelathakumary dan Rajamony, 2004; Syukur et al., 2011), jumlah buah per tanaman (Lestari et al., 2006; Syukur et al., 2011). 
Tabel 1. Rekapitulasi rataan dan rentang data bobot per tanaman, bobot per buah, dan jumlah buah

\begin{tabular}{|c|c|c|c|c|}
\hline \multicolumn{2}{|c|}{ Genotipe } & Bobot per Tanaman (g) & Bobot per Buah $(\mathrm{g})$ & Jumlah Buah (buah) \\
\hline \multirow[t]{2}{*}{ IPB C160 } & Rataan & 42.44 & 0.92 & 43.93 \\
\hline & Rentang & $10.08-16.89$ & $0.79-1.10$ & $11.33-104.00$ \\
\hline \multirow[t]{2}{*}{ IPB C293 } & Rataan & 35.76 & 1.00 & 40.52 \\
\hline & Rentang & $20.74-74.13$ & $0.80-1.13$ & $13.67-84.67$ \\
\hline \multirow[t]{2}{*}{ IPB C291 } & Rataan & 86.12 & 0.94 & 87.98 \\
\hline & Rentang & $17.53-130.53$ & $0.79-1.15$ & $20.00-150.50$ \\
\hline \multirow[t]{2}{*}{ IPB C145 } & Rataan & 101.68 & 0.92 & 109.13 \\
\hline & Rentang & $26.44-193.28$ & $0.86-1.03$ & $31.00-198.33$ \\
\hline \multirow[t]{2}{*}{ IPB C10 } & Rataan & 72.14 & 0.94 & 77.80 \\
\hline & Rentang & $43.71-125.01$ & $0.85-1.07$ & $53.67-129.67$ \\
\hline \multirow[t]{3}{*}{ F3160291-9 } & Rataan & 83.78 & 1.10 & 71.42 \\
\hline & Rentang & $0.63-417.41$ & $0.48-2.48$ & $1.00-303.00$ \\
\hline & $\mathrm{KKG}(\%)$ & 107.69 & 30.08 & 88.37 \\
\hline \multirow[t]{3}{*}{ F3160291-3 } & Rataan & 96.01 & 1.42 & 73.97 \\
\hline & Rentang & $2.67-329.22$ & $0.82-2.52$ & $2.00-196.00$ \\
\hline & $\mathrm{KKG}(\%)$ & 60.80 & 24.43 & 43.20 \\
\hline \multirow[t]{3}{*}{ F3145293-19 } & Rataan & 45.54 & 0.92 & 49.38 \\
\hline & Rentang & $0.61-152.80$ & $0.60-1.71$ & $1.00-170.00$ \\
\hline & $\mathrm{KKG}(\%)$ & 59.83 & 18.87 & 48.90 \\
\hline \multirow[t]{3}{*}{ F3145293-7 } & Rataan & 64.76 & 1.07 & 65.37 \\
\hline & Rentang & $3.17-231.41$ & $0.65-1.72$ & $5.00-233.00$ \\
\hline & $\mathrm{KKG}(\%)$ & 81.29 & 16.24 & 58.00 \\
\hline \multirow[t]{3}{*}{ F310293-13 } & Rataan & 61.20 & 0.96 & 63.31 \\
\hline & Rentang & $0.69-237.73$ & $0.63-1.43$ & $1.00-224.00$ \\
\hline & $\mathrm{KKG}(\%)$ & 86.02 & 14.73 & 73.61 \\
\hline \multirow[t]{3}{*}{ F310293-14 } & Rataan & 53.14 & 1.03 & 44.71 \\
\hline & Rentang & $0.55-287.04$ & $0.55-1.80$ & $1.00-212.00$ \\
\hline & $\mathrm{KKG}(\%)$ & 122.76 & 27.55 & 99.10 \\
\hline
\end{tabular}

Hasil analisis korelasi menunjukkan bahwa umur berbunga berkorelasi positif dan sangat nyata terhadap umur panen, karakter yang berkorelasi positif dengan daya hasil (bobot buah per tanaman) adalah tinggi tanaman, jumlah buah, bobot per buah, panjang buah, panjang tangkai, dan diameter buah (Tabel 2). Hal ini sejalan dengan penelitian sebelumnya yang menyatakan bahwa karakter yang berkorelasi positif terhadap bobot buah per tanaman adalah tinggi tanaman (Ganefianti et al., 2006; Sujitno dan Dianawati, 2015), panjang buah, diameter buah (Ganefianti et al., 2006; Syukur et al., 2010c; Sujitno dan Dianawati, 2015), bobot per buah, dan jumlah buah per tanaman (Ganefianti et al., 2006; Syukur et al., 2010c). Syukur et al. (2010c) menjelaskan bahwa hasil analisis lintas menunjukkan jumlah buah per tanaman memberikan pengaruh langsung cukup besar terhadap bobot buah per tanaman, sedangkan panjang buah dan bobot per buah berpengaruh tidak langsung terhadap bobot buah per tanaman melalui jumlah buah. Meski karakter panjang buah dan bobot per buah berpengaruh tidak langsung tapi tetap potensial digunakan sebagai karakter seleksi. Hal tersebut karena karakter dengan pengaruh total yang besar namun berkorelasi negatif atau kecil sekali (diabaikan) maka karakter yang berperan tidak langsung harus dipertimbangkan secara simultan dalam seleksi (Wahyuni et al., 2004).

Sujitno dan Dianawati (2015) menjelaskan bahwa tinggi tanaman cabai rawit berpengaruh terhadap hasil karena tanaman dengan postur yang tinggi akan membentuk percabangan yang banyak sehingga setiap percabangan akan membentuk bunga dan buah yang banyak pula. Amrullah (2000) menyatakan bahwa bobot buah total per tanaman pada cabai merah dipengaruhi secara positif oleh tinggi tanaman. Pada penelitian tanaman tomat yang dilakukan oleh Susi (2006) menunjukkan bahwa peningkatan jumlah cabang tanaman mendukung peningkatan bobot buah per tanaman. Surtinah (2007) menjelaskan bahwa tinggi tanaman dapat dijadikan sebagai acuan untuk memprediksi bobot buah tomat per tanaman. Hermansyah dan Inoriah (2009) dalam penelitian tanaman nilam menyatakan bahwa meningkatnya pembelahan sel pada meristem apikal dan peningkatan pemanjangan sel mengakibatkan pertambahan tinggi tanaman, kemudian diikuti oleh peningkatan jumlah cabang dapat meningkatkan jumlah cabang produktif dan menghasilkan jumlah bunga dan buah lebih banyak. 
Tabel 2. Korelasi antar karakter cabai rawit

\begin{tabular}{lllllllll}
\hline & UB (HST) & UP (HST) & TT $(\mathrm{cm})$ & BT $(\mathrm{g})$ & BB $(\mathrm{g})$ & PB $(\mathrm{cm})$ & PTB $(\mathrm{cm})$ & DB $(\mathrm{mm})$ \\
\hline UP (HST) & $0.524^{* *}$ & & & & & & & \\
TT (cm) & $-0.012^{\text {th }}$ & $0.169^{* *}$ & & & & & & \\
BT (g) & $-0.132^{*}$ & $-0.102^{\text {tn }}$ & $0.468^{* *}$ & & & & & \\
BB (g) & $0.036^{\text {th }}$ & $0.129^{*}$ & $0.527^{* *}$ & $0.542^{* *}$ & & & & \\
PB (cm) & $0.056^{\text {th }}$ & $0.16^{* *}$ & $0.477^{* *}$ & $0.483^{* *}$ & $0.80^{* *}$ & & & \\
PTB (cm) & $0.063^{\text {th }}$ & $0.212^{* *}$ & $0.566^{* *}$ & $0.357^{* *}$ & $0.508^{* *}$ & $0.557^{* *}$ & & \\
DB (mm) & $-0.024^{\text {tn }}$ & $0.014^{\text {th }}$ & $0.36^{* *}$ & $0.322^{* *}$ & $0.612^{* *}$ & $0.345^{* *}$ & $0.364^{* *}$ & \\
JB (buah) & $-0.159^{* *}$ & $-0.178^{* *}$ & $0.338^{* *}$ & $0.842^{* *}$ & $0.348^{* *}$ & $0.311^{* *}$ & $0.146^{* *}$ & $0.163^{* *}$
\end{tabular}

Keterangan: $\quad \mathrm{UB}=$ umur berbunga, $\mathrm{UP}=$ umur panen, $\mathrm{TT}=$ tinggi tanaman, $\mathrm{BT}=$ bobot buah per tanaman, $\mathrm{BB}=\mathrm{bobot}$ per buah, $\mathrm{PB}=$ panjang buah, $\mathrm{PTB}=$ panjang tangkai buah, $\mathrm{DB}=$ diameter buah, $\mathrm{JB}=$ jumlah buah, $*$ = berkorelasi nyata pada taraf $5 \%, * *=$ berkorelasi sangat nyata pada taraf $1 \%$, tn $=$ tidak nyata.

Heritabilitas Arti Luas Karakter Kuantitatif F3 Cabai Rawit

Nilai heritabilitas menjadi dasar dalam penentuan karakter seleksi. Heritabilitas diklasifikasikan berdasarkan kriteria rendah hingga tinggi. Heritabilitas dikatakan tinggi jika nilai heritabilitas lebih besar dari 50\%, cukup tinggi bila nilainya pada 20 hingga $50 \%$, dan rendah bila lebih kecil dari 20\% (Syukur et al., 2015). Pendugaan heritabilitas suatu karakter dipengaruhi oleh enam faktor, yaitu karakteristik populasi yang diuji, jumlah genotipe yang dievaluasi, metode estimasi yang digunakan, keefektifan penilaian, adanya ketidakseimbangan linkage dan rancangan penelitian yang digunakan di lapangan (Fehr, 1987). Hasil analisis menunjukkan bahwa heritabilitas arti luas dari setiap karakter yang diamati memiliki perbedaan nilai untuk setiap genotipe yang diamati (Tabel 3).

Karakter umur berbunga memberikan nilai heritabilitas arti luas yang tinggi hanya pada genotipe F3160291-3, F310293-13, dan F31029313. Arif (2010) dan Hilmayanti (2006) menyatakan bahwa heritabilitas arti luas umur berbunga berada pada kisaran sedang hingga tinggi. Genotipe yang memiliki heritabilitas arti luas tinggi pada karaker umur panen yaitu F3160291-3, F310293-13, dan F310293-14. Menurut Syukur et al. (2010a) umur panen pada tanaman cabai sangat bervariasi tergantung jenis cabai dan lokasi penanamannya. Semua genotipe F3 memiliki heritabilitas arti luas yang tinggi pada karakter tinggi tanaman kecuali genotipe F3145293-19 dan F3145293-7. Hasil analisis nilai heritabilitas arti luas pada karakter bobot per tanaman berada pada kriteria luas untuk semua genotipe kecuali F3145293-19, bobot per buah menunjukkan kriteria tinggi untuk semua genotipe F3. Hal ini sejalan dengan penelitian sebelumnya yang menunjukkan bahwa karakter bobot buah per tanaman memiliki nilai heritabilitas arti luas pada kriteria tinggi (Streelathakumary dan
Rajamony, 2004; Marame et al., 2008; Syukur et al., 2010c; Syukur et al., 2011; Qosim et al., 2013; Undang, 2014). Streelathakumary dan Rajamony (2004), Lestari et al. (2006), Marame et al. (2008), Syukur et al. (2010c), Syukur et al. (2011), Qosim et al. (2013), serta Hapshoh (2016) menyatakan hasil yang sama dengan hasil penelitian ini tentang nilai heritabilitas karakter bobot per buah.

Hasil analisis heritabilitas panjang buah menunjukkan bahwa semua genotipe memiliki nilai heritabilitas arti luas pada kriteria tinggi (Tabel 3). Hal ini sejalan dengan penelitian sebelumnya yang pernah dilakukan oleh Marame et al. (2008), Syukur et al. (2011), dan Hapshoh (2016). Semua genotipe F3 memiliki nilai heritabilitas arti luas pada karakter panjang tangkai buah dengan kriteria tinggi kecuali pada genotipe F3145293-19. Berdasakan hal tersebut, penampilan panjang tangkai buah masih dapat digolongkan kedalam karakter kuantitatif yang relatif sedikit dipengaruhi oleh faktor lingkungan (Stommel dan Griesbach, 2008). Hasil analisis karakter diameter buah menunjukkan bahwa 5 genotipe F3 memiliki heritabilitas arti luas pada kriteria tinggi (lebih dari 50\%) dan hanya pada genotipe F3145293-7 yang menunjukkan nilai heritabilitasnya sedang (50\%). Heritabilitas jumlah buah per tanaman berada pada kriteria sedang hingga tinggi, hal ini menunjukkan bahwa sebagian besar genotipe F3 cabai rawit yang digunakan dalam penelitian ini memiliki pengaruh genetik yang relatif besar terhadap jumlah buah per tanaman. Penelitian sebelumnya tentang pewarisan karakter cabai rawit yang dilakukan Qosim et al. (2013) dan Undang (2014) menunjukkan bahwa karakter jumlah buah memiliki heritabilitas arti luas dengan kriteria tinggi, Syukur et al. (2010c) menunjukkan bahwa jumlah buah per tanaman memiliki haritabilitas arti luas pada kriteria sedang. 
Bul. Agrohorti 5 (2): 213-225 (2017)

Tabel 3. Nilai duga komponen ragam dan heritabilitas arti luas tiap karakter populasi F3 cabai rawit

\begin{tabular}{|c|c|c|c|c|c|}
\hline Genotipe & $\sigma^{2} E$ & $\sigma^{2} G$ & $\sigma^{2} \mathrm{P}$ & $\mathrm{h}_{\mathrm{bs}}(\%)$ & Kriteria \\
\hline \multicolumn{6}{|c|}{ F3160291-9 } \\
\hline Umur Berbunga (HST) & 5.12 & 2.11 & 7.22 & 29 & Sedang \\
\hline Umur Panen (HST) & 74.49 & 11.87 & 86.36 & 14 & Rendah \\
\hline Tinggi Tanaman $(\mathrm{cm})$ & 14.06 & 202.75 & 216.81 & 94 & Tinggi \\
\hline Bobot per Tanaman (g) & 1.244 .73 & 8.139 .54 & 9.384 .27 & 87 & Tinggi \\
\hline Bobot per Buah (g) & 0.01 & 0.11 & 0.12 & 92 & Tinggi \\
\hline Panjang Buah (cm) & 0.04 & 0.49 & 0.53 & 92 & Tinggi \\
\hline Panjang Tangkai Buah (cm) & 0.02 & 0.12 & 0.14 & 87 & Tinggi \\
\hline Diameter Buah (mm) & 0.10 & 0.67 & 0.77 & 87 & Tinggi \\
\hline Jumlah Buah (buah) & 1.104 .72 & 3.983 .10 & 5.087 .82 & 78 & Tinggi \\
\hline \multicolumn{6}{|c|}{ F3160291-3 } \\
\hline Umur Berbunga (HST) & 5.12 & 5.86 & 10.98 & 53 & Tinggi \\
\hline Umur Panen (HST) & 74.49 & 97.52 & 172.01 & 57 & Tinggi \\
\hline Tinggi Tanaman (cm) & 14.06 & 103.58 & 117.64 & 88 & Tinggi \\
\hline Bobot per Tanaman (g) & 1.244 .73 & 3.407 .83 & 4.652 .56 & 73 & Tinggi \\
\hline Bobot per Buah (g) & 0.01 & 0.12 & 0.13 & 93 & Tinggi \\
\hline Panjang Buah (cm) & 0.04 & 0.55 & 0.6 & 93 & Tinggi \\
\hline Panjang Tangkai Buah $(\mathrm{cm})$ & 0.02 & 0.04 & 0.06 & 70 & Tinggi \\
\hline Diameter Buah (mm) & 0.10 & 0.69 & 0.79 & 88 & Tinggi \\
\hline Jumlah Buah (buah) & 1.104 .72 & 1.020 .80 & 2.125 .52 & 48 & Sedang \\
\hline \multicolumn{6}{|c|}{ F3145293-19 } \\
\hline Umur Berbunga (HST) & 1.33 & 0.44 & 1.78 & 25 & Sedang \\
\hline Umur Panen (HST) & 33.52 & 14.89 & 48.41 & 31 & Sedang \\
\hline Tinggi Tanaman $(\mathrm{cm})$ & 35.75 & 14.51 & 50.26 & 29 & Sedang \\
\hline Bobot per Tanaman (g) & 741.50 & 742.28 & 1.483 .79 & 50 & Sedang \\
\hline Bobot per Buah (g) & 0.01 & 0.03 & 0.04 & 83 & Tinggi \\
\hline Panjang Buah (cm) & 0.04 & 0.05 & 0.09 & 57 & Tinggi \\
\hline Panjang Tangkai Buah (cm) & 0.02 & 0.02 & 0.04 & 46 & Sedang \\
\hline Diameter Buah (mm) & 0.16 & 0.26 & 0.42 & 62 & Tinggi \\
\hline Jumlah Buah (buah) & 1.201 .06 & 583.03 & 1.784 .09 & 33 & Sedang \\
\hline \multicolumn{6}{|c|}{ F3145293-7 } \\
\hline Umur Berbunga (HST) & 1.33 & 0.80 & 2.13 & 38 & Sedang \\
\hline Umur Panen (HST) & 33.52 & 3.35 & 36.87 & 9 & Rendah \\
\hline Tinggi Tanaman (cm) & 35.75 & 27.12 & 62.87 & 43 & Sedang \\
\hline Bobot per Tanaman (g) & 741.50 & 2.770 .74 & 3.512 .25 & 79 & Tinggi \\
\hline Bobot per Buah (g) & 0.01 & 0.03 & 0.04 & 84 & Tinggi \\
\hline Panjang Buah (cm) & 0.04 & 0.11 & 0.17 & 73 & Tinggi \\
\hline Panjang Tangkai Buah (cm) & 0.02 & 0.07 & 0.09 & 78 & Tinggi \\
\hline Diameter Buah (mm) & 0.16 & 0.16 & 0.32 & 50 & Sedang \\
\hline Jumlah Buah (buah) & 1.201 .06 & 1.437 .41 & 2.638 .47 & 54 & Tinggi \\
\hline
\end{tabular}

Keterangan: $\sigma^{2} \mathrm{E}$ : ragam lingkungan, $\sigma^{2} \mathrm{G}$ : ragam genetik, $\sigma^{2} \mathrm{P}$ : ragam fenotipe, $\mathrm{h}_{\mathrm{bs}}$ : nilai heritabilitas arti luas 
Tabel 3. Nilai duga komponen ragam dan heritabilitas arti luas tiap karakter populasi F3 cabai rawit (lanjutan)

\begin{tabular}{|c|c|c|c|c|c|}
\hline Genotipe & $\sigma^{2} \mathrm{E}$ & $\sigma^{2} \mathrm{G}$ & $\sigma^{2} \mathrm{P}$ & $\mathrm{h}_{\mathrm{bs}}(\%)$ & Kriteria \\
\hline \multicolumn{6}{|c|}{ F310293-13 } \\
\hline Umur Berbunga (HST) & 1.35 & 5.27 & 6.62 & 80 & Tinggi \\
\hline Umur Panen (HST) & 37.43 & 68.27 & 105.70 & 65 & Tinggi \\
\hline Tinggi Tanaman $(\mathrm{cm})$ & 33.69 & 92.01 & 125.70 & 73 & Tinggi \\
\hline Bobot per Tanaman (g) & 352.51 & 2.771 .07 & 3.123 .59 & 89 & Tinggi \\
\hline Bobot per Buah (g) & 0.01 & 0.02 & 0.03 & 69 & Tinggi \\
\hline Panjang Buah $(\mathrm{cm})$ & 0.06 & 0.1 & 0.16 & 60 & Tinggi \\
\hline Panjang Tangkai Buah (cm) & 0.03 & 0.11 & 0.13 & 81 & Tinggi \\
\hline Diameter Buah (mm) & 0.21 & 0.28 & 0.49 & 57 & Tinggi \\
\hline Jumlah Buah (buah) & 593.55 & 2.171 .69 & 2.765 .24 & 79 & Tinggi \\
\hline \multicolumn{6}{|c|}{ F310293-14 } \\
\hline Umur Berbunga (HST) & 1.35 & 3.80 & 5.14 & 74 & Tinggi \\
\hline Umur Panen (HST) & 37.43 & 45.23 & 82.66 & 55 & Tinggi \\
\hline Tinggi Tanaman (cm) & 33.69 & 79.72 & 113.41 & 70 & Tinggi \\
\hline Bobot per Tanaman (g) & 352.51 & 4.255 .51 & 4.608 .03 & 92 & Tinggi \\
\hline Bobot per Buah (g) & 0.01 & 0.08 & 0.09 & 80 & Tinggi \\
\hline Panjang Buah $(\mathrm{cm})$ & 0.06 & 0.15 & 0.21 & 70 & Tinggi \\
\hline Panjang Tangkai Buah $(\mathrm{cm})$ & 0.03 & 0.2 & 0.22 & 89 & Tinggi \\
\hline Diameter Buah (mm) & 0.21 & 0.95 & 1.16 & 82 & Tinggi \\
\hline Jumlah Buah (buah) & 593.55 & 1.963 .10 & 2.556 .65 & 77 & Tinggi \\
\hline
\end{tabular}

Keterangan: $\sigma^{2} \mathrm{E}$ : ragam lingkungan, $\sigma^{2} \mathrm{G}$ : ragam genetik, $\sigma^{2} \mathrm{P}$ : ragam fenotipe, $\mathrm{h}_{\mathrm{bs}}$ : nilai heritabilitas arti luas.

\section{Seleksi dan Kemajuan Seleksi Genotipe F3 Cabai} Rawit

Karakter yang digunakan sebagai kriteria seleksi untuk daya hasil selain berkorelasi positif dengan daya hasil, juga harus memiliki nilai heritabilitas yang tinggi sehingga akan diwariskan pada generasi berikutnya (Wirnas et al., 2006). Mengacu pada hasil analisis keragaman genetik, korelasi karakter, dan heritabilitas arti luas maka ditentukan karakter seleksi untuk genotipe F3160291-9 adalah tinggi tanaman, bobot buah per tanaman, bobot per buah, panjang buah, panjang tangkai buah, diameter buah, dan jumlah buah per tanaman. Genotipe F3160291-3 memiliki kriteria seleksi yang terdiri dari karakter umur panen, tinggi tanaman, bobot buah per tanaman, bobot per buah, panjang buah, dan jumlah buah per tanaman. Genotipe F3145293-19 memiliki kriteria seleksi yang terdiri dari karakter tinggi tanaman, bobot buah per tanaman, bobot per buah, dan jumlah buah per tanaman. Genotipe F3145293-7 memiliki kriteria seleksi yang terdiri dari karakter tinggi tanaman, bobot buah per tanaman, bobot per buah, panjang buah, panjang tangkai buah, dan jumlah buah per tanaman. Genotipe F310293-13 memiliki kriteria seleksi yang terdiri dari karakter umur panen, tinggi tanaman, bobot buah per tanaman, bobot per buah, panjang tangkai buah, dan jumlah buah per tanaman. Genotipe F310293-14 memiliki kriteria seleksi yang terdiri dari karakter tinggi tanaman, bobot buah per tanaman, bobot per buah, panjang buah, panjang tangkai buah, diameter buah, dan jumlah buah per tanaman.

Hasil seleksi indeks pada populasi F3 cabai rawit menghasilkan 10 tanaman dengan indeks tertinggi pada setiap genotipenya. Individu tanaman cabai rawit yang terseleksi dari genotipe F3160291-9 adalah tanaman nomor 60, 54, 50, 48, 46, 45, 3, 53, 49, dan 43. Pada genotipe F3160291-3 memberikan hasil seleksi berupa individu nomor 52, 59, 45, 6, 34, 48, 8, 56, 54, dan 50. Seleksi pada genotipe F3145293-19 menghasilkan sepuluh tanaman terbaik yaitu tanaman nomor 56, 26, 36, 38, 28, 57, 53, 35, 50, dan 32. Pada seleksi genotipe F3145293-7 menghasilkan sepuluh tanaman terbaik yaitu tanaman nomor 3, 4, 6, 1, 44, 15, 60, 56, 42, dan 7. Pada genotipe F310293-13 menghasilkan sepuluh tanaman terseleksi yaitu tanaman nomor 49, 47, 20, 58, 52, 5, 54, 59, 40, dan 46. Pada genotipe F310293-14 menghasilkan sepuluh tanaman terbaik yaitu tanaman nomor 53, 55, 54, 
50, 60, 47, 58, 46, 17, dan 48. Semua individu terseleksi ini memiliki keunggulan sesuai dengan kriteria seleksi yang digunakan pada setiap genotipe, namun secara umum individu terseleksi ini memiliki daya hasil yang lebih baik dari populasi awalnya. Namun perlu dilakukan analisis kemajuan seleksi untuk mempertegas bahwa ada perbaikan rataan populasi terseleksi dibandingkan populasi awalnya.

Hasil analisis menunjukkan bahwa semua karakter seleksi memiliki dugaan persentase kemajuan seleksi yang tergolong cukup besar hingga besar kecuali pada karakter umur panen genotipe F41602913 dan F410293-13, panjang tangkai buah genotipe F4145293-7, serta tinggi tanaman pada genotipe F4145293-19 (Tabel 4). Hal ini sesuai Susiana (2006) yang menjelaskan bahwa kemajuan seleksi pada umur panen tergolong rendah.

Nilai dugaan kemajuan yang paling besar terdapat pada karakter bobot buah per tanaman dengan nilai antara 28.84 sampai dengan 136.66 dan karakter jumlah buah pertanaman dengan nilai antara 14.70 sampai dengan 88.76 (Tabel 4). Dugaan nilai kemajuan seleksi karakter bobot buah per tanaman pada genotipe F4160291-9 yaitu sebesar 136.66. Rataan bobot buah per tanaman populasi F3160291-9 adalah 83,78 g dan setelah satu siklus seleksi atau pada populasi F4160291-9 diperkirakan terjadi peningkatan sebesar $136.66 \mathrm{~g}$.

Umur panen genotipe F4160291-3 memiliki nilai dugaan kemajuan seleksi sebesar 4,25. Hal tersebut berarti bahwa poulasi F3160291-3 yang memiliki umur panen rata-rata pada 76.45 HST, setelah satu siklus seleksi diperkirakan umur panen lebih cepat 4,25 HST yaitu menjadi 72.20 HST. Nilai tengan umur panen cabai rawit genotipe hasil seleksi masih lebih genjah dibandingkan cabai rawit spesies $C$. frutescens yang terjadai antara 85-90 HST (Rukmana, 2002).

Tabel 4. Dugaan kemajuan seleksi pada populasi F4 hasil seleksi

\begin{tabular}{|c|c|c|c|c|c|}
\hline Karakter & $\bar{x}_{t}$ & $\bar{x}_{p}$ & $\mathrm{~S}$ & $\Delta G$ & $\% \Delta G$ \\
\hline \multicolumn{6}{|c|}{ F4160291-9 } \\
\hline Tinggi Tanaman $(\mathrm{cm})$ & 66.06 & 47.43 & 18.63 & 17.51 & 36.91 \\
\hline Bobot per Tanaman $(\mathrm{g})$ & 240.86 & 83.78 & 157.08 & 136.66 & 163.12 \\
\hline Bobot per Buah $(\mathrm{g})$ & 1.46 & 1.10 & 0.36 & 0.33 & 30.05 \\
\hline Panjang Buah $(\mathrm{cm})$ & 4.47 & 3.51 & 0.95 & 0.88 & 25.01 \\
\hline Panjang Tangkai Buah $(\mathrm{cm})$ & 3.21 & 2.72 & 0.49 & 0.43 & 15.74 \\
\hline Diameter Buah (mm) & 8.45 & 7.77 & 0.68 & 0.59 & 7.57 \\
\hline Jumlah Buah (buah) & 184.80 & 71.42 & 113.38 & 88.76 & 124.28 \\
\hline \multicolumn{6}{|c|}{ F4160291-3 } \\
\hline Umur Panen (HST) & 69.00 & 76.45 & -7.45 & -4.25 & -5.55 \\
\hline Tinggi Tanaman $(\mathrm{cm})$ & 53.43 & 47.25 & 6.18 & 5.44 & 11.51 \\
\hline Bobot per Tanaman $(\mathrm{g})$ & 182.79 & 96.01 & 86.77 & 63.34 & 65.97 \\
\hline Bobot per Buah $(\mathrm{g})$ & 1.94 & 1.42 & 0.53 & 0.49 & 34.49 \\
\hline Panjang Buah $(\mathrm{cm})$ & 5.07 & 4.13 & 0.94 & 0.87 & 21.07 \\
\hline Jumlah Buah (buah) & 104.60 & 73.97 & 30.63 & 14.70 & 19.88 \\
\hline \multicolumn{6}{|c|}{ F4145293-19 } \\
\hline Tinggi Tanaman $(\mathrm{cm})$ & 40.17 & 34.65 & 5.52 & 1.60 & 4.62 \\
\hline Bobot per Tanaman (g) & 103.22 & 45.54 & 57.69 & 28.84 & 63.34 \\
\hline Bobot per Buah $(\mathrm{g})$ & 1.10 & 0.92 & 0.19 & 0.15 & 16.85 \\
\hline Jumlah Buah (buah) & 108.40 & 49.38 & 59.03 & 19.48 & 39.45 \\
\hline \multicolumn{6}{|c|}{ F4145293-7 } \\
\hline Tinggi Tanaman $(\mathrm{cm})$ & 47.09 & 39.52 & 7.57 & 3.25 & 8.23 \\
\hline Bobot per Tanaman $(\mathrm{g})$ & 148.19 & 64.76 & 83.43 & 61.74 & 95.34 \\
\hline Bobot per Buah $(\mathrm{g})$ & 1.29 & 1.07 & 0.22 & 0.19 & 17.62 \\
\hline Panjang Buah $(\mathrm{cm})$ & 3.64 & 3.27 & 0.37 & 0.27 & 8.30 \\
\hline Panjang Tangkai Buah (cm) & 2.63 & 2.42 & 0.20 & 0.16 & 6.53 \\
\hline Jumlah Buah (buah) & 141.80 & 65.37 & 76.43 & 43.57 & 66.65 \\
\hline
\end{tabular}

Keterangan: $\quad \bar{x}_{t}=$ nilai tengah populasi terseleksi, $\bar{x}_{p}=$ nilai tengah populasi awal, $\mathrm{S}=$ diferensial seleksi, $\Delta G=$ kemajuan seleksi 
Tabel 4. Dugaan kemajuan seleksi pada populasi F4 hasil seleksi (lanjutan)

\begin{tabular}{|c|c|c|c|c|c|}
\hline Karakter & $\bar{x}_{t}$ & $\bar{x}_{p}$ & $\mathrm{~S}$ & $\Delta G$ & $\% \Delta G$ \\
\hline \multicolumn{6}{|c|}{ F410293-13 } \\
\hline Umur Panen (HST) & 69.30 & 70.29 & -0.99 & -0.64 & -0.91 \\
\hline Tinggi Tanaman (cm) & 52.54 & 41.47 & 11.07 & 8.08 & 19.48 \\
\hline Bobot per Tanaman (g) & 152.98 & 61.20 & 91.78 & 81.69 & 133.48 \\
\hline Bobot per Buah $(\mathrm{g})$ & 1.11 & 0.96 & 0.15 & 0.11 & 11.07 \\
\hline Panjang Tangkai Buah (cm) & 2.81 & 2.55 & 0.26 & 0.21 & 8.27 \\
\hline Jumlah Buah (buah) & 147.80 & 63.31 & 84.49 & 66.75 & 105.44 \\
\hline \multicolumn{6}{|c|}{ F410293-14 } \\
\hline Tinggi Tanaman $(\mathrm{cm})$ & 48.42 & 42.27 & 6.15 & 4.30 & 10.18 \\
\hline Bobot per Tanaman $(\mathrm{g})$ & 155.91 & 53.14 & 102.77 & 94.55 & 177.92 \\
\hline Bobot per Buah $(\mathrm{g})$ & 1.44 & 1.03 & 0.41 & 0.33 & 31.85 \\
\hline Panjang Buah (cm) & 3.61 & 3.12 & 0.49 & 0.35 & 11.07 \\
\hline Panjang Tangkai Buah $(\mathrm{cm})$ & 3.33 & 2.79 & 0.54 & 0.48 & 17.35 \\
\hline Diameter Buah (mm) & 9.96 & 8.72 & 1.24 & 1.01 & 11.63 \\
\hline Jumlah Buah (buah) & 105.10 & 44.77 & 60.33 & 46.45 & 103.76 \\
\hline
\end{tabular}

Keterangan: $\quad \bar{x}_{t}=$ nilai tengah populasi terseleksi, $\bar{x}_{p}=$ nilai tengah populasi awal, $\mathrm{S}=$ diferensial seleksi, $\Delta G=$ kemajuan seleksi

Secara umum cabai rawit spesies $C$. annиum hasil seleksi dari enam genotipe F3 memiliki nilai tengah umur berbunga dan umur panen yang lebih genjah dibandingkan dengan spesies $C$. frutescens, tinggi tanaman lebih dari 40 $\mathrm{cm}$, bobot buah per tanaman antara 100-230 g, bobot per buah lebih dari $1 \mathrm{~g}$, panjang buah antara $3.63-4.99 \mathrm{~cm}$, panjang tangkai buah $2.63-3.38 \mathrm{~cm}$, diameter buah antara $8.49-9.97 \mathrm{~mm}$, dan jumlah buah per tanaman 73.20-134.50 buah.

\section{KESIMPULAN}

Hasil analisis menunjukkan bahwa pada populasi F3 karakter umur panen, tinggi tanaman, bobot buah per tanaman, bobot per buah, panjang buah, panjang tangkai buah, diameter buah, dan jumlah buah per tanaman memiliki keragaman genetik sempit hingga luas. Karakter umur berbunga memiliki keragaman genetik yang sempit. Semua karakter pengamatan berkorelasi positif terhadap daya hasil kecuali umur berbunga dan umur panen. Nilai heritabilitas arti luas yang tergolong rendah hingga tinggi terdapat pada karakter umur panen. Heritabilitas arti luas sedang hingga tinggi pada karakter umur berbunga, tinggi tanaman, panjang tangkai buah, diameter buah, dan jumlah buah per tanaman. Heritabilitas arti luas dengan kriteria tinggi terdapat pada karakter bobot buah per tanaman, bobot per buah, dan panjang buah. Nilai kemajuan seleksi yang paling besar ditunjukkan oleh karakter bobot buah per tanaman dan jumlah buah per tanaman pada semua genotipe.

\section{DAFTAR PUSTAKA}

Alnopri. 2004. Variabilitas genetik dan heritabilitas sifat-sifat pertumbuhan bibit tujuh genotipe kopi robusta-arabica. Jurnal Ilmu-ilmu Pertanian Indonesia 6(2):91-96.

Amrullah. 2000. Tingkat kandungan klorofil daun dan kontribusinya serta pengaruh pemupukan NPKMg dan pemberian metanol terhadap kandungan klorofil, pertumbuhan, dan produktivitas tanaman cabai merah (Capsicum annuum L.). Tesis. Institut Pertanian Bogor. Bogor.

Arif A.B. 2010. Pendugaan parameter genetic beberapa karakter kualitatif fan kuantitatif pada tiga kelompok cabai (Capsicum annuиm L.). [tesis] Institut Pertanian Bogor. Bogor.

Awmack C.S., Leather S.R. 2002. Host plant quality and fecun-dity in herbivorous insects. Ann. Rev. Entomol. 47: 817- 844.

Blackman R.L., Eastop V.F. 2000. Aphids on the World's Crop: An Identification and Information Guide 2nd eds. John Wiley and Sons, New York (US).

[BMKG] Badan Meteorologi Klimatologi dan Geofisika. 2016. Data iklim Stasiun Klimatologi Dramaga tahun 2015 dan 2016. BMKG, Bogor.

[BPS] Badan Pusat Statistik. 2014. Survei sosial ekonomi nasional 2009-2013. [Internet] [diunduh 2015 Ags 18] tersedia pada 
http://microdata.bps.go.id/mikrodata/index. $\mathrm{php} / \mathrm{catalog} / 220$.

[Disperindag Jabar] Dinas Perindustrian dan Perdagangan Jawa Barat. 2016. Harga ratarata cabe rawit merah naik sebesar 13,16 persen.

http://disperindag.jabarprov.go.id/news/deta il/internal/2016/

07/25:03:19508c75c8507a2ae5223dfd2faeb 98122. [3 Agustus 2016].

Falconer D.S. 1981. Introduction to Quantitative Genetics. Longman, London (UK) and New York (US).

Fehr W. R. 1987. Principles of Cultivar Development. Vol 1. Macmillan, New York (US) and London (UK).

Firdaus M. 2015. Ekonomi Hortikultura. IPB Press, Bogor.

Ganefianti D.W., Yulian, Suprapti A.N. 2006. Korelasi dan sidik lintas antara pertumbuhan, komponen hasil dan hasil dengan gugur buah pada tanaman cabai. J. Akta Agrosia 9(1):1-6.

Greenleaf W.H. 1986. Pepper Breeding. In Bassett M.J. (Ed.). Breeding Vegetables Crops. AVI Publishing Co., Westport, Conecticut (US).

Hapshoh S. 2016. Pewarisan karakter kualitatif dan kuantitatif pada persilangan cabai besar dan cabai rawit serta ketahanannya terhadap penyakit layu fusarium. Tesis. Institut Pertanian Bogor. Bogor.

Hermansyah Y., Inoriah E. 2009. Penggunaan pupuk daun dan manipulasi jumlah cabang yang ditinggalkan pada panen kedua tanaman nilam. J. Akta Agrosia 12(2):194203.

Hilmayanti I., Dewi W., Murdaningsih, Rahardja M., Rostini N., Setiamihardja R. 2006. Pewarisan karakter umur berbunga dan ukuran buah cabai merah (Capsicum annuиm L.). Zuriat 17(1):86-93.

[IPGRI] International Plant Genetic Resources Institute. 1995. Descriptor for Capsicum (Capsicum spp.). IPGRI, Roma (ITA).
[Kementan] Kementerian Pertanian. 2014a. Luas Panen Sayuran di Indonesia, 2010-2014. http://www.pertanian.go.id/ATAP2014HORTI-pdf/100-LPSayuran.pdf [4 Oktober 2015].

[Kementan] Kementerian Pertanian. 2014b. Produksi Cabai Rawit Menurut Provinsi, 2010-2014. http://www.pertanian.go.id/ATAP2014HORTI-pdf/204-Prod-CabeRawit.pdf Oktober 2015].

Kennedy J.S., Stroyan H.L.G. 1959. Biology of aphids. Ann. Rev. Entomol. 4: 139-160.

Kusandriani Y., Muharam A. 2005. Produksi Benih Cabai. Balai Penelitian Tanaman Sayur, Bandung.

Lestari A.D., Dewi W., Qosim W.A., Rahardja M., Rostini N., Setiamihardja R.. 2006. Variabilitas genetik dan heritabilitas karakter komponen hasil dan hasil lima belas genotip cabai merah. Zuriat 17(1): 94 -102 .

Maharijaya A., Syukur M. 2014. Menghasilkan Cabai Keriting Kualitas Premium. Penebar Swadaya, Jakarta.

Marame F., Desalegne L., Singh H., Fininsa C., Sigvald R. 2008. Genetic components and heritability of yield and yield related traits in hot pepper. Res. J. Agric. Biol. Sci. 4(6): 803-809.

Pawardi S. 2013. Perkembangan harga dan pasok cabe serta bawang merah. http://www.kemendag.go.id/ en/news/2013/08/19/perkembangan-hargadan-pasok-cabe-serta-bawang-merah-olehsoekam-parwadi [7 Maret 2015].

Permadi A.H., Kusandriani Y. 2006. Pemuliaan tanaman cabai. Hal. 22-35. Dalam A. Santika (ed.). Agribisnis Cabai. Penebar Swadaya, Jakarta

Poehlman J.M., Sleeper D.A. 1995. Breeding Field Crops. Iowa State University Press, Ames (US).

Qosim W.A., Rachmadi M., Hamdani J.S., Nuri I. 2013. Penampilan fenotipik, variabilitas, dan heritabilitas 32 genotipe cabai merah 
berdaya hasil tinggi. J. Agron. Indonesia 41(2):140-146.

Rukmana R.H. 2002. Usaha Tani Cabai Rawit. Yogyakarta (ID): Kanisius

Sreelathakumary I., Rajamony L. 2004. Variability, heritability and genetic advance in chilli (Capsicum annuum L.). J. Tro. Agri. 42 (2): 35 - 37.

Stommel J.R., Griesbach R.J. 2008. Inheritance of fruit, foliar and plant habit attributes in Capsicum. J. Amer. Soc. Hort. Sci. 133:396-407.

Sujitno E., Dianawati M. 2015. Produksi panen berbagai varietas unggul baru cabai rawit (Capsicum frutescens) di lahan kering Kabupaten Garut, Jawa Barat. Dalam: Setyawan A.D., Sugiyarto, Pitoyo A., Hernawan U.E. dan Widiastuti A., (Eds). Manajemen Biodiversitas dalam Melindungi, Mempertahankan dan Memperkaya Sumber daya Genetik dan Pemanfaatannya. Seminar Nasional Masyarakat Biodiversitas Indonesia; Yogyakarta, 21 Maret 2015.

Surtinah. 2007. Kajian tentang hubungan pertumbuhan vegetatif dengan produksi tanaman tomat (Lycopersicum esculentum, Mill). J. Ilmiah Pertanian 4(1):1-9.

Susi N. 2006. Aplikasi pemberian beberapa dosis Pos dan konsentrasi Liquinox Start terhadap pertumbuhan dan produksi tomat (Lycopersicum esculentum, Mill). J. Ilmiah Pertanian 3(1):17-28.

Susiana E. 2006. Penduga nilai heritabilitas, variabilitas, dan evaluasi kemajuan genetik beberapa karakter agronomi genotipe cabai (Capsicum annuum L.) F4. Skripsi. Institut Pertanian Bogor. Bogor.

Suwandi, Sumarni N., Bahar F.A. 1999. Aspek Agronomi Cabe. Jakarta (ID) : Penebar Swadaya

Syukur M., Sujiprihati S., Yunianti R. 2015. Teknik Pemuliaan Tanaman. Jakarta (ID) : Penebar Swadaya

Syukur M., Sujiprihati S., Yunianti R., Kusumah D.A. 2010a. Evaluasi daya hasil cabai hibrida dan daya adaptasi di empat lokasi dalam dua tahun. J. Agron. Indonesia 38(1): 43-51.

Syukur M., Sujiprihati S., Yunianti R., Kusumah D.A. 2011. Pendugaan ragam genetik dan heritabilitas karakter komponen hasil beberapa genotipe cabai. J. Agrivigor 10(2):148-156.

Syukur M., Sujiprihati S., Yunianti R., Nida K. 2010c. Pendugaan komponen ragam, heritabilitas dan korelasi untuk menentukan kriteria seleksi cabai (Capsicum annuum L.) populasi F5. J. Hort. Indonesia 1(2):7480 .

Syukur M., Sujiprihati S., Yunianti R., Undang. 2010b. Diallel analysis using hayman method to study genetic parameters of yield omponents in pepper (Capsicum annuиm L.). Hayati J. Biosci. 17(4):183-188.

Undang. 2014. Identifikasi dua spesies cabai rawit dan pewarisan karakter penting pada cabai rawit spesies Capsicum annuиm L. [tesis] Institut Pertanian Bogor. Bogor.

Utama K.D., Bagus I.G.N., Siadi I.K., Nyana I.D.N., Suastika G. 2015 Pengaruh penggunaan mulsa plastic terhadap kelimpahan serangga Myzus persicae pada tanaman cabai rawit (Capsicum frutescens L.). JAT 4(1):74-80.

Wahyuni T.S., Setiamihardja R., Hermiati N., Hendroatmodjo K.H. 2004. Variabilitas genetik, heritabilitas dan hubungan antara hasil umbi dengan beberapa karakter kuantitatif dari 52 genotipe ubi jalar. Zuriat 15(2):109-117.

Wirnas D., Widodo I., Sobir, Trikoesoemaningtyas, Sopandie D. 2006. Pemilihan karakter agronomi untuk menyusun indeks seleksi pada 11 populasi kedelai generasi F6. Bul. Agron. 34(1):1924.

Yunianti R., Sastrasumarjo S., Sujiprihati S., Surahman M., Hidayat S. 2010. Kriteria seleksi untuk perakitan varietas cabai tahan Phytophtora capsici Leonian. J. Agron. Indonesia 38(2):122-129. 